\title{
The effect of coppice management on stump volume recovery in mechanized operations
}

\author{
Muedanyi Ramantswana ${ }^{1}$ (D) Andrew Mcewan $^{1} \cdot$ Raffaele Spinelli $^{2}$
}

Received: 8 May 2017 / Accepted: 12 July 2017 /Published online: 31 July 2017

(C) INRA and Springer-Verlag France SAS 2017

\begin{abstract}
- Key message Coppice stands result in slightly higher stump waste compared with planted stands, when felled mechanically by a harvester.

- Context The large demand for wood fibre requires efficient production and cost-effective practices throughout the supply chain.

- Aims The purpose of the study was to quantify the amount of volume lost to excessive stump height in coppiced and planted stands.

- Methods Stump height was measured on similar eucalypt stands that differed only for their origin: coppiced or planted. The study sample comprised of 543 planted stems and 851 coppice stems; of which 365 grew as double stems and 486 as single.
\end{abstract}

\section{Handling Editor: Aaron R Weiskittel}

Contribution of the co-authors All authors contributed to the compilation of this article. Andrew McEwan was involved in designing of experiment and writing the paper. Dr. Raffaele Spinelli was responsible for running data analysis and writing results as well as writing up the paper. The research was coordinated by Muedanyi Ramantswana.

Muedanyi Ramantswana

Muedanyi.Ramantswana@nmmu.ac.za

Andrew Mcewan

Andrew@cmo.co.za

Raffaele Spinelli

spinelli@ivalsa.cnr.it

1 Nelson Mandela Metropolitan University, Private Bag X6531, George 6530, South Africa

2 CNR IVALSA, Via Madonna del Piano 10, Sesto Fiorentino (FI), Italy
- Results Stump waste was highest for coppiced double stumps, smallest for coppiced single stumps and intermediate for planted tree stumps. All differences were statistically significant, but the difference between coppiced single stumps and planted tree stumps was much smaller $(20 \%)$ than the difference between coppiced double stumps and the rest (220-260\%). Regression analysis showed that stump waste volume increased with tree volume, and this effect was twice as large for coppiced double stumps compared with the other treatments. Stump waste seemed very small in both relative and absolute terms and is unlikely to offset the large benefits accrued through coppice management and mechanization.

- Conclusion Comparison with previous stump height studies indicates that the results obtained in this experiment for planted eucalypt may have general value and could be extended to other coppice stands, although with caution.

Keywords Volume $\cdot$ Waste $\cdot$ Harvester Plantation · Eucalypt, volume recovery

\section{Introduction}

Recent attempts to replace fossil raw materials with renewable feedstock have created new opportunities for forestry, which may supply the growing bio-economy with a wide array of new products (Barreiro et al. 2016). The result is a further growth in the global demand for wood fibre (Stringer 2006) that may reach 1.7 billion $\mathrm{m}^{3}$ by 2030 (INDUFOR 2012). Matching these large demands requires efficient production, which is the key for producers to survive in a highly competitive global market.

Cost-effective solutions must be implemented throughout the supply chain, and in the forest significant cost reduction can be achieved through coppicing, if the stand is established 
with species that resprout after felling. In that case, the initial cost of stand establishment is spread over two or more rotations, depending on stand type and stump vigour.

Another way to decrease supply cost is to introduce mechanized harvesting, which boosts labour productivity while increasing work safety and comfort (Bell 2002). Mechanization may also offset the shortage of skilled labour, which is being experienced in many countries where economic development creates better employment opportunities than offered by traditional agricultural and forest work (Spinelli et al. 2013).

Unfortunately, modern forestry equipment is generally designed for use in high forests, not coppice stands (Spinelli et al. 2002). That is especially the case of cut-to-length harvesters that are designed for treating single stems and are known to handle coppice stands with some difficulty (Spinelli et al. 2010). Stem crowding on the same stump hinders harvester work, and requires much ability from the operator (Suchomel et al. 2012). As a result, the challenge offered by stump crowding can only be successfully met by the most experienced operators (McEwan et al. 2016).

Several studies have focused on the effect of stump crowding on harvester productivity and cost (Ramantswana et al. 2013; Spinelli et al. 2016), but none has address its effect on value recovery. Stump crowding represents a physical obstacle to harvester work, preventing the harvester to firmly grab the stem to be cut. Since stems tend to diverge with distance from their insertion on the stump, operators often counter the effect of stump crowding by grabbing and cutting target coppice stems higher than they would do for planted stems (Spinelli et al. 2007). That may result in increased stump height and decreased value recovery, because part of the potential harvest is left on the cut stump. Many studies have already shown that the introduction of mechanized harvesting to coppice stands does result in increased stump height compared with conventional motor-manual harvesting (Schweier et al. 2015). However, all previous studies have addressed stump damage, not value recovery (Spinelli et al. 2017; Suchomel et al. 2011). For such reason, all these studies have compared different harvesting techniques (e.g. manual and mechanical) on the same coppice stands, and not the same technique on different stands (e.g. coppiced and planted). In fact, value losses could be estimated by comparing different studies, but that is bound to offer little accuracy and reliability. Accurate figures can only be obtained when the same mechanized technique is applied to coppiced and planted stands.

This study was designed to offer a first contribution to the issue of value recovery in mechanized coppice operation: the study takes the case of eucalypt plantations as an example, but aims at producing general knowledge that can be applied to other coppice stands, after suitable adaptation. Plantation forestry was elected as a case study because it offers ideal experimental conditions, characterized by less variability than encountered in more traditional coppice stands. Furthermore, within plantation compartments, it is easier to find adjacent coppiced and planted blocks with similar characteristics.

For the purpose of this study, value recovery is equated to volume recovery. That is consistent with the simplified product target of most eucalypt plantations, which are managed for the exclusive production of pulpwood. At the same time, the identification of value recovery with volume recovery makes all calculations easier to follow than it would be the case if multiproduct sorting was adopted. In the study, volume recovery is described as the ratio between the volume actually harvested and the volume potentially available on the compartment (Bentley and Harper 2004). Value recovery expresses the same concept, but refers to monetary value, not brute volume. Managers should pay attention to maximize volume and value recovery through the production chain (Haynes and Visser 2004). In many cases, value recovery can be increased by re-evaluating harvesting systems (Hall and Han 2006).

In particular, the objectives of this study were (1) to quantify the amount of volume lost to excessive stump height in coppiced and planted stands; (2) to compare the amount of volume lost due to excessive stump heights in coppiced and planted stands and (3) to determine if there is a relationship between volume losses and stem size, and if the eventual relationship is different for coppiced and planted stands. The null hypothesis is that of no statistically significant differences in stump height between planted and coppiced trees, regardless of whether the coppiced stumps carried one or more stems each. That would amount to say that the operation of the harvester head is not affected by the higher basal sweep or the presence of multiple stems on the same stump that characterize coppiced trees.

\section{Materials and methods}

\subsection{Study site and design}

The field work of the research was conducted on a Mondi (major commercial timber company) plantation situated in the New Hanover area of Kwazulu-Natal, South Africa. Six clearfelling compartments were randomly selected based on the list of available compartments for clearfelling at the time of the study. The identification numbers and coordinates for coppiced compartments were D006 (29 $16^{\prime} 11^{\prime \prime} \mathrm{S}$; 30²8'02"

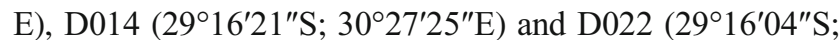
$\left.30^{\circ} 25^{\prime} 30^{\prime \prime} \mathrm{E}\right)$. The harvester also operated in compartment D020 (29 $\left.15^{\prime} 52^{\prime \prime} \mathrm{S} ; 30^{\circ} 27^{\prime} 11^{\prime \prime} \mathrm{E}\right)$ which was planted (Table 1). 
Table 1 Description of the research compartments

\begin{tabular}{|c|c|c|c|c|}
\hline Compartment & D006 & D014 & D022 & D020 \\
\hline Species & $\begin{array}{l}\text { E. grandis } \\
\text { (coppiced) }\end{array}$ & $\begin{array}{l}\text { E. grandis } \\
\text { (coppiced) }\end{array}$ & $\begin{array}{l}\text { E. grandis } \\
\text { (coppiced) }\end{array}$ & $\begin{array}{l}\text { E. grandis } \\
\text { (planted) }\end{array}$ \\
\hline Area (ha) & 11.20 & 25.60 & 22.60 & 5.3 \\
\hline Age (years) & 8 & 5 & 8 & 7 \\
\hline Trees per hectare & 1296 & 921 & 855 & 1229 \\
\hline Average tree volume $\left(\mathrm{m}^{3}\right)$ & 0.165 & 0.275 & 0.253 & 0.214 \\
\hline Average DBH (cm) & 13.1 & 17.7 & 17.6 & 18.3 \\
\hline Slope $^{\mathrm{a}}(\%)$ & $0-10$ & $0-10$ & $0-10$ & $0-10$ \\
\hline Sample size & 734 & 97 & 378 & 542 \\
\hline
\end{tabular}

${ }^{a}$ Values indicate the range of ground slope

\subsection{Stump volume waste data collection}

The volume of timber wasted due to excessive stump height was measured immediately after the harvester completed felling each plot. Stems were felled by a Waratah HTH616 harvester head mounted on a tracked Hitachi Zaxis 200-3 excavator carrier. The harvester head specifications are described in Table 2. Both machine operators used in the research had over 5 years' experience in operating excavatorbased harvesters.

Standing trees were measured and marked to derive stem volume; their stumps were also marked with the same numbers. In the coppiced double treatment, the two stems growing on the same stumps received the same number, as the reference was indeed the stump. The diameters at breast height (DBH) of all marked stems were measured using a diameter calliper at a height of $1.37 \mathrm{~m}$, which is the standard height for diameter readings in South Africa (Bredenkamp 2000). Tree height was measured for selected trees, using a Vertex

Table 2 Harvester head specifications

\begin{tabular}{ll}
\hline Make & Waratah \\
Model & HTH616 \\
Service hours & 12,000 \\
Year of manufacture & 2005 \\
Max diameter capacity $(\mathrm{cm}):$ & 68 \\
Weight $(\mathrm{kg})$ & 1680 \\
Maximum feed speed $(\mathrm{m} / \mathrm{s})$ & 5 \\
Type of rollers & 45 degree double-edged \\
& debarking \\
Computer type & Timbermatic 10 \\
Bar type & Carlton $3 / 4 "$ \\
Chain type & Oregon $3 / 4 "$ \\
\hline
\end{tabular}

Source: Waratah 2011 hypsometer with a transponder. An average of 20 tree heights were measured per 100 trees recorded.

Paper tags were attached to the base of the tree to identify the stump after felling. Two identically numbered paper tags with the standing stem number were stapled on opposite sides at the base of the tree. Because the stump waste measurement was conducted immediately after the trees were harvested, the paper tags were easy to identify. To avoid losing the tags during tree felling, the tags were usually stapled onto the major root system visible around the base of the stump. When the harvester had felled and processed the marked trees, the stumps were measured and related back to the specific trees that were felled. After felling, the stumps could be covered by slash and stacked logs. Therefore, to enhance the stump-finding and identification process, once the marking of the trees and stumps was complete, a sketch map was drawn to show the original positions of the trees before felling took place.

Stump heights were measured on the upslope side of the stump from ground level to the top of the felling cut (Hall and Han 2006). Any obstacles like branches and bark were removed from around the stump to ensure that the stump was measured correctly. In coppiced stands, stump heights per stem were measured from where the coppice stump was attached to the previous rotation's stump, instead of measuring from the ground. Once the harvester had processed the standing trees, the stump heights and diameters of trees in both the coppiced and planted plots were measured and the remaining volume was calculated. The maximum allowable stump height in pulpwood compartments is $10 \mathrm{~cm}$ (Sappi 2011). Therefore, any stumps which were higher than the specified $10 \mathrm{~cm}$ limit were recorded and the waste volume was determined. To determine the diameter of each stump, the under-bark diameter was measured to the nearest centimetre. To determine the 
diameter of stumps with oval or irregular shapes, the longest and shortest diameters were measured and averaged to determine the diameter of the stump.

The allowable stump height of $10 \mathrm{~cm}$ was deducted from the total stump height and the remaining length was recorded. If the stump height was within the required limits of the maximum allowable stump height of $10 \mathrm{~cm}$, the tree was recorded as having no wood volume loss. Any utilizable volume that remained above the allowable $10 \mathrm{~cm}$ stump height after felling was measured and wood volumes determined. The formula that was used to determine the stump waste volume is shown below.

Stump waste volume $\left(\mathrm{m}^{3}\right)=\frac{\pi \times \mathrm{DBH}^{2} \times \text { height }}{40,000}$ (Hall and Han 2006; Bredenkamp 2000).

The gap between the saw and the base on the harvester head was also measured. This measurement was taken, as sometimes harvester head bases are set too high to protect the cutting saw. The distance between the cutting saw and the base of the head was $10 \mathrm{~cm}$, which matched the minimum stump height requirements. If the gap between the saw and the base had been set higher, then it would have influenced the stump volume recovery results.

\subsection{Data capture and analysis}

All the stump volume waste information was recorded manually and transferred to a Microsoft Excel spreadsheet. The waste volume remaining on each stump was calculated by using the stump waste volume formula. Stump heights were converted from centimetres to metres for waste volume calculations. Taper was not factored into the calculation.

The analysis was conducted for two separate observation units: the single stump and the block. The latter was obtained by randomly grouping stump observations into 10 blocks per treatment, each block containing the same number of stumps. This was done to quantify the frequency of non-conformities, intended as those stumps higher than the $10 \mathrm{~cm}$ specification. Data was analysed statistically using Statview for Windows 5.01 (SAS Institute Inc 1999). As a first step, descriptive statistics were drawn separately for each treatment. Then, the distribution of data was plotted to make a first visual assessment about compliance with the normality assumption. This was formally checked using Ryan-Noyer's test. The data was then checked for homoscedasticity using Bartlett's test.

Linear, normal and homoscedastic data was tested using a general linear model (GLM), which was especially suited to handle unbalanced datasets and was quite powerful. Multiple comparisons were then conducted with the Tukey-Kramer test. While the GLM technique is relatively robust to violations of the statistical assumptions, a conservative approach was preferred and therefore non-normal or heteroscedastic data was handled with non-parametric and post-hoc tests, specifically designed for handling data that violate the statistical assumptions, although less powerful than the GLM and Tukey-Karmer's test. The Kruskal-Wallis test was used for checking the presence of statistically significant differences between groups, and the Mann-Whitney $U$ test for pinning such differences onto specific treatments, which were checked in couples. Both such tests are suitable for data sets flawed by unequal numbers of observations, non-normal distribution of data and heteroscedasticity (SAS Institute Inc 1999). In all analyses, the elected significance level was $\alpha<0.05$.

Finally, quality control (QC) analysis was applied to the block data for each treatment, based on the assumption that stump height was a work quality parameter and therefore the variations of stump height within subsequent blocks in the same treatment could be used to determine if the cutting process was in control. If one of the treatments configured as an out-of-control process, then one could demonstrate the presence of specific difficulties encountered with that one treatment. For these analyses, specific blocks were assumed as natural subgroups, each containing the same number of items (50 to 70 stems depending on the treatment). Each treatment was considered separately, and the analysis aimed at defining whether that one treatment was in-control or not, rather than at comparing treatments directly.

\section{Results}

The analysis of the stump-level data indicated that single stems from coppice regeneration (here coppice single) had a significantly smaller DBH and height, compared with the other two treatments (Table 3). As a result, the above-ground harvest volume (henceforth: stem volume) obtained from the average coppice stump after reduction to one single stem was 20 and 50\% smaller compared with the above-ground harvest volumes offered by a planted tree and by a coppice stump where two shoots had been released, respectively. Releasing two shoots seemed to overcompensate the production deficit of coppice stumps in their second rotation, with regard to planted trees in their first rotation.

Stump height was significantly lower for the coppiced single stumps, compared with the other two treatments, while the stump height difference between coppiced double stumps and the planted tree stumps was small $(40 \mathrm{~mm})$ and non-significant.

Taken in absolute terms $\left(\mathrm{m}^{3}\right.$ per stump), stump waste was highest for coppiced double stumps, smallest for coppiced single stumps and intermediate for planted tree stumps. All 
Table 3 Results for the individual stump observations

\begin{tabular}{|c|c|c|c|c|c|c|c|c|}
\hline \multirow{3}{*}{$\begin{array}{l}\text { Treatment } \\
\text { Observations } \\
\text { Parameter }\end{array}$} & \multirow{3}{*}{$n$} & \multirow{2}{*}{\multicolumn{2}{|c|}{$\frac{\text { Coppice double }}{365}$}} & \multirow{2}{*}{\multicolumn{2}{|c|}{$\begin{array}{l}\text { Coppice single } \\
486\end{array}$}} & \multirow{2}{*}{\multicolumn{2}{|c|}{$\frac{\text { Planted }}{543}$}} & \multirow{3}{*}{$p$ value } \\
\hline & & & & & & & & \\
\hline & & Mean & $\mathrm{SD}$ & Mean & SD & Mean & $\mathrm{SD}$ & \\
\hline $\mathrm{DBH}$ & $\mathrm{cm}$ & $17.3 \mathrm{a}$ & 4.9 & $15.2 \mathrm{~b}$ & 5.1 & $17.0 \mathrm{a}$ & 4.7 & $<0.0001$ \\
\hline Height & $\mathrm{m}$ & $23.1 \mathrm{a}$ & 4.0 & $21.3 b$ & 4.4 & $23.0 \mathrm{a}$ & 4.3 & $<0.0001$ \\
\hline Stem volume & $\mathrm{m}^{3}$ & $0.3299 a$ & 0.2245 & $0.1802 b$ & 0.1643 & $0.2310 \mathrm{c}$ & 0.1555 & $<0.0001$ \\
\hline Stump height* & $\mathrm{cm}$ & $3.49 \mathrm{a}$ & 0.08 & $2.20 \mathrm{~b}$ & 0.08 & $3.05 \mathrm{a}$ & 0.07 & 0.0007 \\
\hline Stump waste & $\mathrm{m}^{3}$ & $0.0013 a$ & 0.0034 & $0.0005 b$ & 0.0018 & $0.0006 \mathrm{c}$ & 0.0015 & $<0.0001$ \\
\hline Waste over stem & $\%$ & $0.45 \mathrm{a}$ & 1.18 & $0.33 b$ & 1.08 & $0.36 \mathrm{~b}$ & 0.98 & $<0.0001$ \\
\hline
\end{tabular}

Different lowercase letters indicate that the difference between the means for the different treatments is significant at the $<0.05$ level. Stump height* refers to the excess stump height above the $10 \mathrm{~cm}$ specification

$S D$ standard deviation

differences were statistically significant, but the difference between coppiced single stumps and planted tree stumps was much smaller $(20 \%)$ than the difference between coppiced double stumps and the rest (220-260\%). When expressing waste in relative terms ( $\%$ waste over stem volume), the statistical significance of any differences between treatments was weakened by the balancing effect of stem volume differences. As a result, differences between coppiced single stumps and planted tree stumps lost any statistical significance, because stem volume balancing combined with a very small absolute volume difference. On the other hand, the difference between coppiced double stumps and the other treatments was large enough to maintain its statistical significance. In any case, wasted stump volume always represented less than $0.5 \%$ of total harvest volume.

Regression analysis showed that stump waste volume increased with stem volume, and this effect was twice as large for coppiced double stumps compared with the other treatments (Table 4). That was consistent with the information provided by the comparison of means, and indicated that the increment ratio was about the same across the whole range of stem volumes. In fact, the regression shown in Table 4 should be taken more as a confirmation of existing dynamics than as a tool for predicting volume losses, due to its small explanatory power (correlation coefficient $=0.166$ ). On the other hand, the high statistical significance $(p<0.001)$ makes it a good indicator of trends (Fig. 1).

Analysis of block-level data confirmed the general trends already observed in the stump-level data, and namely (1) that the coppiced single treatment offered the smallest stem size and harvest volume and (2) that the coppiced double treatment incurred the highest waste, both in absolute and relative terms (Table 5). If at all, blocking weakened the capacity of the analyses to discriminate between treatments, but it did not result in a cancellation or a reversal of trends. On the other hand, it allowed exploring the frequency of nonconformities (i.e. cutting above the $10 \mathrm{~cm}$ height specification), which was significantly different between treatments. The frequency of non-conformities in the coppiced double treatment was one third higher than recorded for the planted treatment, and three quarters higher than recorded for coppiced single treatments. In short, leaving two shoots on a coppiced stump resulted in a significant increase of overcutting occurrences.

This issue was further explored with QC analysis, assuming that overcutting occurrences could be considered as manufacturing errors. However, the X-bar line charts for the three treatments show that the process is in-control for all treatments, because stump height falls (barely, at times) within the control limits (Fig. 2). However, the larger space between the control limits for the coppiced double treatment hints at a somewhat higher difficulty to keep up with tight cutting height specs when handling double stems.

Table 4 Regression equation for stump waste ( $\mathrm{m}^{3}$ per stump) as a function of stem volume per stump and treatment

\begin{tabular}{lllll}
\hline $\mathrm{m}^{3}$ waste $=$ & $a$ stem $+b$ Dummy $D \times$ stem & & \\
\hline \multicolumn{6}{c}{$r^{2}$ adj $=0.166 ; n=1394 ; F=140.010 ; p<0.0001$} & \\
& Coeff & SE & $T$ & $p$ value \\
$a$ & 0.002 & $2.589 \times 10^{-4}$ & 7.931 & $<0.0001$ \\
$b$ & 0.002 & $3.859 \times 10^{-4}$ & 5.607 & 0.0044 \\
\hline
\end{tabular}

Where stem $=\mathrm{m}^{3}$ solid volume of the above-ground mass insisting on the stump (sum of two stems if a double-stemmed coppiced stump); Dummy $D=$ indicator variable for coppice double stumps, $=1$ if double, $=0$ if single or planted 


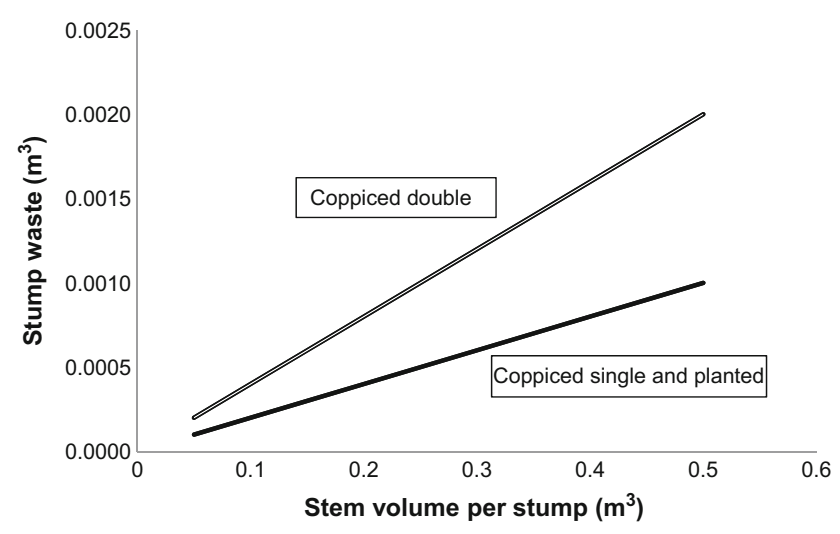

Fig. 1 Relationship between stump waste and stem volume per stump, for different treatments

\section{Discussion}

\subsection{Corroboration and generalization}

The stump height figures recorded in this study are within the range reported by previous studies, which confirms the generally representative value of the current experiment. In particular, the only other study on stump height available for a eucalypt plantation felled with a harvester reports mean stump height values between 8 and $22 \mathrm{~cm}$ for coppiced multiple stumps (Magagnotti et al. 2011). The large field of variation reported in that study is the consequence of steep terrain, which causes the upslope side of the stump to be taller than the downslope side. That fully covers the range of heights recorded in this experiment, which varies from 13 to $17 \mathrm{~cm}$.

Other studies conducted on different stands and with different technologies report similar stump height figures, which supports the general value of the current experiment. Boston and Dystart (2000) indicate that mean stump height may vary from 7 to $14 \mathrm{~cm}$ for mechanically felled radiata pine, when using a range of feller buncher heads. Higher values are reported by Han and Renzie (2005), who studied the effect of slope, stump diameter and species on stump height and found mean values between 14 and $20 \mathrm{~cm}$-highlighting the crucial effect of slope on volume recovery. More recently, Spinelli et al. (2017) have reported stump height figures between 5 and $15 \mathrm{~cm}$ for the mechanical felling of traditional oak coppice in Italy. All these values match those found in the present study and support cautious generalization.

\subsection{Significance}

Conducted with scientific methods under controlled conditions, this study confirms that stump crowding results in increased cutting height, when mechanized harvester felling is introduced. While there is little merit in confirming logical expectations, this study can be credited with producing accurate numerical figures. These figures are very important because they show that the value loss caused from stump crowding is quite small, and likely much smaller than the additional cost of reverting to manual felling. Furthermore, the study shows that releasing two shoots per stump results in a much higher yield than releasing just one shoot. Therefore, if managers were tempted to release one shoot only in order to facilitate harvester work and minimize volume losses, then this study warns them against it by indicating that the benefit is not worth the cost.

However, it is important to consider the effects of stumps on the circulation of extraction units. Tall stumps represent obstacles in the stand, which may hinder machine circulation, cause accelerated machine wear and decrease operator comfort. When that is the case, it

Table 5 Results for the block observations

\begin{tabular}{|c|c|c|c|c|c|c|c|}
\hline \multicolumn{2}{|l|}{ Treatment } & \multicolumn{2}{|c|}{ Coppiced double } & \multicolumn{2}{|c|}{ Coppiced single } & \multicolumn{2}{|l|}{ Planted } \\
\hline \multicolumn{2}{|l|}{ Observations } & \multicolumn{2}{|l|}{10} & \multicolumn{2}{|l|}{10} & \multicolumn{2}{|l|}{10} \\
\hline & & Mean & SD & Mean & SD & Mean & SD \\
\hline $\mathrm{DBH}$ & $\mathrm{cm}$ & $17.4 \mathrm{a}$ & 3.1 & $15.2 \mathrm{a}$ & 2.2 & $17.0 \mathrm{a}$ & 0.7 \\
\hline Height & M & $23.2 \mathrm{a}$ & 2.4 & $21.3 b$ & 1.9 & $23.0 \mathrm{a}$ & 0.8 \\
\hline Stem volume & $\mathrm{m}^{3}$ & $12.04 \mathrm{a}$ & 4.459 & $8.76 \mathrm{~b}$ & 3.285 & $12.542 \mathrm{a}$ & 1.176 \\
\hline Stump height & $\mathrm{Cm}$ & $3.47 \mathrm{a}$ & 1.69 & $2.18 \mathrm{a}$ & 1.46 & $3.04 \mathrm{a}$ & 1.67 \\
\hline Stump waste & $\mathrm{m}^{3}$ & $0.0464 \mathrm{a}$ & 0.0250 & $0.0221 b$ & 0.0177 & $0.0320 \mathrm{~b}$ & 0.0215 \\
\hline Waste & $\% \mathrm{~m}^{3}$ & $0.43 \mathrm{a}$ & 0.25 & $0.28 \mathrm{~b}$ & 0.27 & $0.25 \mathrm{~b}$ & 0.16 \\
\hline Stumps with waste & $\%$ no. & $41.1 \mathrm{a}$ & 8.9 & $23.1 \mathrm{~b}$ & 11.8 & $29.9 \mathrm{c}$ & 10.8 \\
\hline
\end{tabular}

Different lowercase letters indicate that the difference between the means for the different treatments is significant at the $<0.05$ level SD standard deviation 

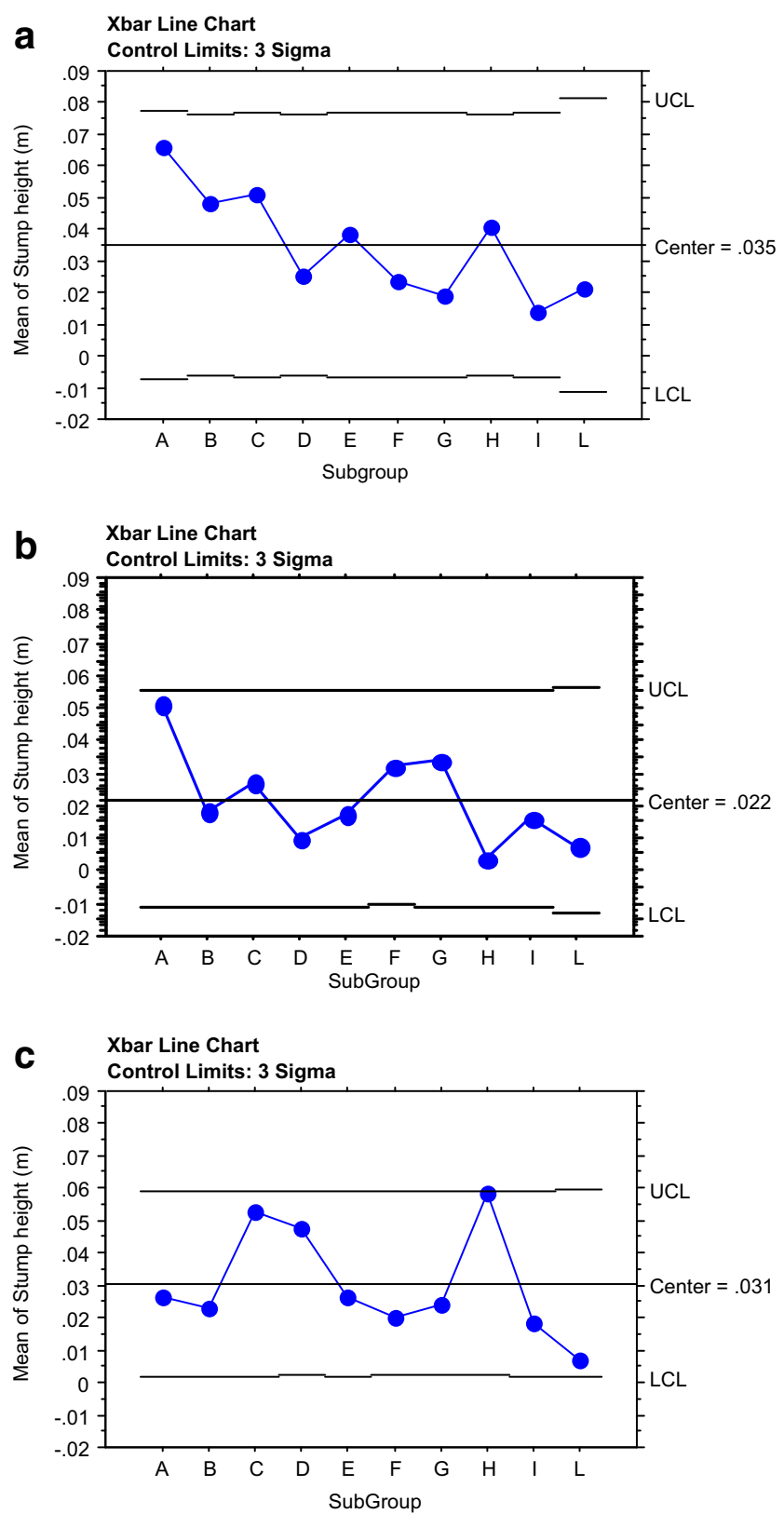

Fig. 2 X-bar charts for the coppiced double (a), coppiced single (b) and planted (c) treatments

is crucial to cut as low as possible, and if despite all attempts some stumps still represented a clear obstacle to machine circulation, then they should be cut lower with a chainsaw (Schweier et al. 2015).

\subsection{Limitations}

Stump volume was calculated by multiplying the stump basal area by its height, as suggested by Hall and Han (2006). This method assumes that the stump is a cylinder and ignores taper. Thus, there is a possibility that losses were underestimated. However, the short length of the excess stump portion is likely to minimize the difference between actual volume and cylinder volume.

Coppiced stump height was measured from the original stump insertion point as this is the only point where the harvester could make a cut. However, if a machine such as a feller buncher with a disc saw had been used for felling the trees, then stump heights could have been lower, because these machines would have been able to cut below the insertion point; hence, our study only reflects harvester use. In general, our study may have underestimated volume losses, to some extent. However, a possible measurement bias would not cancel or reverse the differences found in this study, but it would only magnify them. Therefore, the trends found here would stay confirmed.

Two operators were used for the study, both with a long experience of harvester work in Eucalyptus clearfelling operations. The purpose of the study was not to gauge operator effect on stump heights but to evaluate and compare stump heights in planted and coppiced stands. However, it is important to note that some of the variability in the study results may be derived from operator effect. Boston and Dysart (2000) indicated that operator experience did not seem to have an impact on stump height, as the least experienced operator in their study was in the group with the lowest stumps. However, Hall and Han (2006) indicate that the desire to achieve high production maybe a more significant factor on operator felling technique than the acquired experience.

\section{Conclusion}

In this study, stump waste was highest (absolute and relative terms) for coppiced double stumps, smallest for coppiced single stumps and intermediate for planted tree stumps. Furthermore, it was found that stump volume waste increased with stem volume and this effect was twice as large for coppiced double stumps compared with coppiced single and planted treatments. In all cases, stump waste seemed very small in both relative and absolute terms. Therefore, it is unlikely that the small increase of stump waste recorded in this study may offset the benefits of coppice management (dramatic reduction of regeneration cost) or mechanized harvesting (dramatic reduction of harvesting cost). Forest managers can combine findings from harvester productivity studies with stump waste figures from this study to make informed decisions about the application of harvesters in coppiced stands. Future studies could replicate the experiment on other coppice types to see whether the results found for eucalypt plantations also stand for other coppice forests, and they could consider 
the influence of human factors on stump heights, in order to ascertain collective reasons for poor value recovery.

Acknowledgements The authors would like to acknowledge the Nelson Mandela Metropolitan University, Sappi and Mondi for support and contributions to ensure this research was possible.

\section{Compliance with ethical standards}

Funding Nelson Mandela Metropolitan University and Sappi forests were responsible for funding the research project.

\section{References}

Barreiro S, Schelhaas M, Kändler G, Antón-Fernández C, Colin A, Bontemps J, Alberdi I, Condés S, Dumitru M, Ferezliev A, Fischer C, Gaspatini P, Gshwantner T, Kindermann G, Kiartansson B, Kovácsevics P, Kucera M, Lundström A, Marin G, Mozgeris G, Nord-Larsen T, Packalen T, Redmond J, Sacchelli S, Sims A, Snorrason A, Stoyanov N, Thürig E, Wikberg P (2016) Overview of methods and tools for evaluating future woody biomass availability in European countries. Ann For Sci 73:823-837

Bell J (2002) Changes in logging injury rates associated with use of fellerbunchers in West Virginia. J Saf Res 33:436-471

Bentley JW, Harper AR (2004) Georgia harvest and utilization study. NC: U.S. Department of Agriculture Forest Service, Southern Research Station

Boston K, Dysart G (2000) A comparison of felling techniques on stump height and log damage with economic interpretations. West J Appl For 15:59-61

Bredenkamp B (2000) Volume and mass of logs and standing trees. In: Owen, D.L. (ed.). South African forestry handbook, Vol. 1. The Southern African Institute of Forestry, pp. 167-174; p.194

Hall R, Han H (2006) Improvements in value through low stump heights: mechanized versus manual felling. West J Appl For 21:33-38

Han H, Renzie C (2005) Effect of ground slope, stump diameter and species on stump height for feller-buncher and chainsaw felling. Int J For Eng 16:81-88

Haynes HJG, Visser RJM (2004) An applied hardwood value recovery study in the Appalachian hardwood region of Virginia and West Virginia. Int J For Eng 15:25-31
INDUFOR (2012) Forest Stewardship Council: strategic review of the future of forest plantations. INDUFOR [Online] http://www.fao.org/ forestry/42701-090e8a9fd4969cb334b2ae7957d7b1505.pdf [Accessed 22 February 2017]

Magagnotti N, Nati C, Pari L, Spinelli R, Visser R (2011) Assessing the cost of stump-site debarking in eucalypt plantations. Biosyst Eng 110:443-449

McEwan A, Magagnotti N, Spinelli R (2016) The effects of number of stems per stool on cutting productivity in coppiced Eucalyptus plantations. Silva Fenn. 50 (id 1448) 14 p

Ramantswana M, McEwan A, Steenkamp J (2013) A comparison between excavator-based harvester productivity in coppiced and planted Eucalyptus grandis compartments in KwaZulu-Natal, South Africa. South For: J For Sci 75:239-246

Sappi (2011) Mpumalanga pre-harvest agreement and compartment planning: utilizable timber waste Pietermaritzburg Sappi Cascades p3

SAS Institute Inc (1999) StatView reference. SAS Publishing, Cary, NC, USA. ISBN-1-58025-162-5. p 84-93

Schweier J, Spinelli R, Magagnotti N, Becker G (2015) Mechanized coppice harvesting with new small-scale feller-bunchers: results from harvesting trials with newly manufactured felling heads in Italy. Biomass Bioenergy 72:85-94

Spinelli R, Owende PMO, Ward S (2002) Productivity and cost of CTL harvesting of Eucalyptus globulus stands using excavator-based harvesters. For Prod J 52:67-77

Spinelli R, Cuchet E, Roux P (2007) A new feller-buncher for harvesting energy wood: results from a European test programme. Biomass Bioenergy 31:205-210

Spinelli R, Hartsough BR, Magagnotti N (2010) Productivity standards for harvesters and processors in Italy. For Prod J 60:226-235

Spinelli R, Magagnotti N, Facchinetti D (2013) Logging companies in the European mountain: an example from the Italian Alps. Int J For Eng 24:109-120

Spinelli R, Cacot E, Mihelic M, Nestorovski L, Mederski P, Tolosana E (2016) Techniques and productivity of coppice harvesting operations in Europe: a meta-analysis of available data. Ann For Sci 73: $1125-1139$

Spinelli R, Pari L, Aminti G, Magagnotti N, Giovannelli A (2017) Mortality, re-sprouting vigor and physiology of coppice stumps after mechanized cutting. Ann For Sci 74:1-5

Stringer C (2006) Forest certification and changing global commodity chains. J Econ Geogr 6:701-722

Suchomel C, Becker G, Pyttel P (2011) Fully mechanized harvesting in aged oak coppice stands. For Prod J 61:290-296

Suchomel C, Spinelli R, Magagnotti N (2012) Productivity of processing hardwoods from coppice forests. Croat J For Eng 33:39-47 